\title{
A Comparative Analysis on Performance and Emission Characteristics of Four Stroke CI Engine with Diesel, Hazelnut and Corn Bio-Diesel Blends as Fuel
}

\author{
T. Krishnaiah ${ }^{1}$, Dr. V. Pandurangadu ${ }^{2}$ \\ ${ }^{1}$ M.Tech, (Ph.D) Department of Mechanical, Gates Institute of Technology, Gooty, Anantapur, Andhra Pradesh, India \\ ${ }^{2} \mathrm{Ph} . \mathrm{D}$, Professor, Department of Mechanical, Rector, JNTUA, Anantapuramu, Anantapur, Andhra Pradesh, India
}

\begin{abstract}
An experimental analysis was carried out to investigate two types of non edible oils (Hazelnut and Corn) blended with conventional diesel fuel approximately with proportions of $5 \%, 10 \%, 15 \%, 20 \%$ and $25 \%$ by volume in a 4-stroke single cylinder, vertical, water cooled, Compression Ignition engine. Number of experimental trials were conducted with the above bio-diesel blends as fuel operated in the engine working at all loads from minimum to maximum. An analysis was made to compare the results such as exhaust emission characteristics like NOx emissions, CO emissions, smoke density, and total and partially unburned hydrocarbons. Performance parameters like brake specific fuel consumption(BSFC), brake Thermal efficiency(BTHE), and exhaust gas temperatures(EGT) for all blends prepared by blending the bio-diesels mentioned above with conventional diesel fuel separately with different proportions listed in the work. In this work CI engine is giving better performance with blend B20 for both diesels used as fuel when compare with remaining blends of both bio-diesels. But when compare with these B20 blends are showing marginal decrease in the performance parameters. Engine working with bio-diesel blends as fuel are showing noticeable reduction in exhaust emissions like carbon monoxides $(\mathrm{CO})$, hydro carbons $(\mathrm{HC})$ and slight increase in oxides of nitrogen(NOx) when compared with conventional neat diesel fuel.. Bio-diesel blend prepared from hazelnut bio-diesel showing better properties next to diesel fuel when compared with remaining bio-diesels used in the present work. This blend is showing better engine performance and decreased engine emissions when compared with Corn bio-diesel blends. After hazel nut oil immediately corn is giving better performance.
\end{abstract}

Keywords: hazelnut, corn, Biodiesel, Emissions, Performance parameters

\section{Introduction}

Along with techniques related to the engine to meet emission regulations imposed [1-4], researchers of engine are also focusing their interest on the domain of fuel-related techniques, such as for example oxygenated fuels which are able to decrease particulate emissions [5-10] and alternative gaseous fuels that are renewable in nature.

To develop the sources of alternate fuel, many countries of the world are stepping forward by paying considerable attention. Alternative fuel which are produced from the products of agriculture are reducing the oil imports in the world. They are also supporting agricultural industries, which increases the farming incomes despite of all these advantages they are also reducing the exhaust emissions. The bio fuels which are considered as most promising fuels are the fuels derived from vegetable oils, bio alcohols, and vegetable oils. Among all the industries in the world bio fuel production is one of the rapidly growing industries. In spark ignition engines bio-ethanol is the primary alternative to gasoline. Vegetable oil and their derived bio fuel as well as diesel fuel mixing with small proportions of ethanol are alternative fuel for compression ignition engines. Whereas other alternative fuels like bio-mass derived hydro-carbon fuel, bio-butanol and hydrogen are being research at present which are considered as alternative fuel for next generation.

Apart from renewability, bio-fuels are more advantageous than normal diesel in some aspects like they are having very less sulphur content and aromatic contents, higher lubricity, higher flash point, non-toxicity and higher bio-degradability. On the other side the disadvantages of bio-fuels includes very high pour point, very high viscosity, the lower cetane number, lower volatility and lower calorific value. One of the great disadvantages of bio-fuel is its highly increased viscosity, which is approximately 10-20 times greater than normal diesel fuel. More over short term tests by using biofuels are giving promising results but when engine has been operated for longer periods then problems are appearing, which includes more carbon deposits, injector coking with trumpet formation, piston oil ring sticking, as well as the thickness of engine lubricating oil also increases. The following methods are adopted to avoid the problems associated with their high viscosity. Micro emulsification with methanol or ethanol blending in small blend ratios with diesel fuel, cracking, preheating and conversion in to bio-fuel mainly through the transisterification process. [22-25].

The advantages of bio-diesels as diesel fuel, apart from renewability, are the minimal sulfur and aromatic content, the higher flash point, the higher lubricity, the higher cetane number, and the higher biodegradability and non-toxicity. On the other hand, their disadvantages include the higher viscosity (though much lower than the vegetable oils one), the higher pour point, the lower calorific value and the lower volatility. Furthermore, their oxidation stability is lower, they are hygroscopic, and as solvents they may cause corrosion of components, attacking some plastic materials used for seals, hoses, paints and coatings. They show increased dilution and 


\section{International Journal of Science and Research (IJSR) \\ ISSN (Online): 2319-7064 \\ Index Copernicus Value (2013): 6.14 | Impact Factor (2015): 6.391}

polymerization of engine sump oil, thus requiring more frequent oil changes.

Because of all the above reasons, maximum up to $25 \%$ of bio-fuels and vegetables are generally accepted as blends with diesel fuel and can be used in existing diesel engines without modifications. Experimental studies on the CI engines with the use of bio-fuels blending with neat diesel have been reported.

The present experimental work studies and compares the above bio-fuels of various origins, in blending with ordinary diesel fuel, by fuelling a single cylinder, direct injection, naturally aspirated CI engines. A companion paper extended the present investigation for hazelnut oil and its methyl esters for different blend ratios, followed by another paper dealing with their heat release and stastical analysis using insulated combustion chamber of the same engine.

As mentioned above, the results of performance and emissions have been evaluated by this research work by using blends of neat diesel fuel with twobio-fuels (Hazelnut and Corn) [28], in the single-cylinder, water-cooled, direct injection, 'kirlosker' diesel engine concerning the present work. The interpretation of the experimental measurements was based on the differences of properties between the fuels tested.

Most of the experimental works reported on the use of biofuels in the compression ignition engines are referred to mainly single-cylinder naturally aspirated engines have been used only one or two bio-fuel oils. But the present research work steps forward in reporting on the use of twobio-fuel oils on a single-cylinder, four stroke and water-cooled diesel engine.

Widely differing chemical and physical properties of biofuels against those of diesel fuels, are combining with the theoretical aspects of diesel engine combustion, and are used to aid the correct interpretation of the observed engine emissions and performance wise behavior.

\section{Description of the Engine Test Facility}

Facilities to monitor and control engine variables were installed on a test-bed, Kirloskar single cylinder, four stroke, vertical, water cooled, compression ignition engine (Fig. 1) was used and mounted on the ground. The test engine was directly coupled to an eddy current dynamometer with suitable switching and control facility for loading the engine. Engine specifications were as follows: bore \& stroke, $87.5 \mathrm{~mm}$ x 110 $\mathrm{mm}$; compression ratio, 17.5: 1; speed, $1500 \mathrm{rpm}$; fuel timing, $27^{\circ}$ by spill (btdc); clearance volume, $37.8 \mathrm{cc}$; and rated power, $5 \mathrm{hp}$.

For fuel consumption measurement a tank and flow metering system is used for various blend samples as follows. A piezometer of known volume was used with the measurement of time for the complete evacuation of the sample fuel which is feeding to the engine. In order to have a quick drain of a fuel sample, including the return fuel from injector and pump and refilling of fuel metering system with new fuel sample a system is provided with valves and pipes.
A system which is used for the measurement of exhaust gases consists of group of analyzers for measuring carbon monoxide (CO), oxides of nitrogen $\left(\mathrm{NO}_{\mathrm{x}}\right)$, hydrocarbons $(\mathrm{HC})$, smoke density (SD), particulate and soot. The concentration of $\mathrm{CO}$ (in ppm) present in the exhaust gases was measured by using 'Signal' Series-7200 non-dispersive infrared analyzer (NDIR) equipped with a 'Signal' Series-2505M Cooler. 'Bosch' RTT-100 opacimeter, is used to measure the smoke level in the exhaust gas the readings of which are provided as equivalent smoke density in $\left(\mathrm{mg}\right.$ of soot/ $\mathrm{m}^{3}$ of exhaust gases). The concentration of nitrogen oxides in ppm (parts per million, by vol.) present in the exhaust gases was measured by using 'Signal' Series-4000 chemiluminescent analyzer (CLA) that was fitted with a thermostatically controlled heated line. The total unburned hydrocarbons concentration (in ppm) present in the exhaust gases was measured with a 'Ratfisch-Instruments' Series RS55 flameionization detector (FID) that was also fitted with a thermostatically controlled heated line.

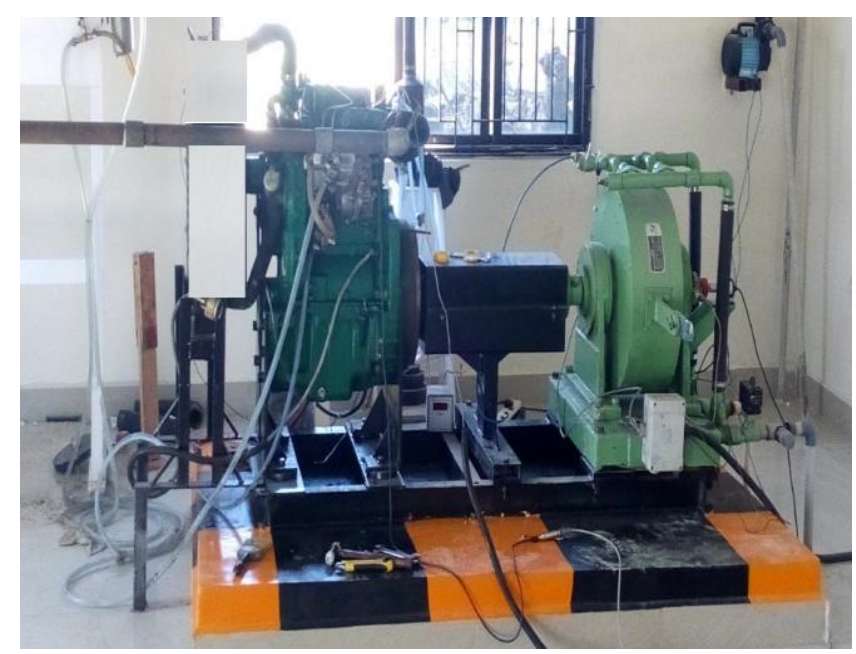

Figure 1: Experimental Setup

Table 1: Engine Specifications And Injection System Basic Data

Engine model and type : Kirlosker single-cylinder, four stroke, compression ignition,

direct injection, water-cooled.

Speed $1500 \mathrm{rpm}$

Engine total displacement $661 \mathrm{~cm} 3$

Bore/stroke $87.5 \mathrm{~mm} / 110 \mathrm{~mm}$

Compression ratio 17.5:1

Maximum power 5.2 HP @ 1500 rpm

Maximum torque 29.0376 Nm @1500rpm

opening pressure $250 \mathrm{bar}$

\section{Properties of Fuels Tested}

Two typical types of straight Bio-diesel oils, viz. Hazelnut and Corn are tested as supplements of the normal diesel fuel, at blend ratios of $05 / 95 \%, 10 / 90 \%, 15 / 85 \%$ and $20 / 80 \%$ $25 / 75 \%$ (by vol.) with the conventional diesel fuel.

Diesel fuels which contains very less amount of sulphur content approximately $(0.035 \mathrm{wt} \%)$ forms the base line for present study. To reduce the viscosity of bio-fuels they are to be de-gummed and refined, nearly the edible type without any pre-heating and adding any additives. All important properties of two bio-fuels and diesel are provided in table- 2 .

\section{Volume 5 Issue 6, June 2016}

www.ijsr.net 


\section{International Journal of Science and Research (IJSR) \\ ISSN (Online): 2319-7064}

Index Copernicus Value (2013): 6.14 | Impact Factor (2015): 6.391

All the values mentioned in the table are the mean values taken from various sites and references mentioned with this paper. In this study it required to note that the cetane number and kinematic viscosity values mentioned are not used computationally. In order to explain qualitatively the relative performance and emissions behavior of different fuel blends they are only referred to for indicative purposes.

Table 2: Fuel Properties

\begin{tabular}{|c|c|c|c|c|}
\hline Fuel & $\begin{array}{c}\text { Density at } \\
15^{0} \mathrm{c} . \\
\mathrm{Kg} / \mathrm{mm}^{3}\end{array}$ & $\begin{array}{c}\text { Kinematic } \\
\text { viscosity at } 40^{\circ} \mathrm{c} . \\
\text { cST }\end{array}$ & $\begin{array}{c}\text { Calorific } \\
\text { value. } \\
\text { MJ/kg }\end{array}$ & $\begin{array}{c}\text { Flash } \\
\text { point }\end{array}$ \\
\hline Diesel & 837 & 1.3 & 42.70 & 369 \\
Hazelnut & 875 & 3.59 & 42.12 & 425 \\
Corn & 873 & 3.62 & 41.14 & 427 \\
\hline
\end{tabular}

Table 3: Accuracy of Measurements and Uncertainty of Computed Results

\begin{tabular}{|c|c|}
\hline Measurements & Accuracy \\
\hline NOx & $\pm 5 \mathrm{ppm}$ \\
HC & $\pm 0.5 \mathrm{ppm}$ \\
CO & $\pm 0.2 \%$ \\
Smoke opacity & $\pm 0.1 \%$ \\
Speed & $\pm 5 \mathrm{rpm}$ \\
Specific fuel consumption & \pm 1.5 \\
Time & $\pm 5 \%$ \\
Torque & $\pm 0.5 \mathrm{Nm}$ \\
Fuel volumetric rat & \pm 1 \\
Power & \pm 1 \\
\hline
\end{tabular}

\section{Experimental Section, Transesterification Process}

To reduce viscosity of vegetable oils, transesterification method is adopted for preparation of biodiesel ${ }^{11}$. In this process, non-edible oil $(1000 \mathrm{ml})$ was taken in a three way flask. In a beaker, sodium hydroxide $(\mathrm{NaOH}, 12 \mathrm{~g})$ and methanol $\left(\mathrm{CH}_{3} \mathrm{OH}, 200 \mathrm{ml}\right)$ were thoroughly mixed until it is properly dissolved. The solution obtained was mixed with nonedible oil in three way flask and stirred properly. Methoxide solution with non-edible oil was heated to $60^{\circ} \mathrm{C}$ and continuously stirred at constant rate for $1 \mathrm{~h}$. The solution is poured down in a separate beaker and is allowed to settle for $4 \mathrm{~h}$. Glycerin settles at the bottom and methyl ester floats at the top (coarse biodiesel). Methyl ester is separated, heated above $100^{\circ} \mathrm{C}$ and maintained for $10-15 \mathrm{~min}$ to remove untreated methanol. Certain impurities like $\mathrm{NaOH}$ etc. are still dissolved in the obtained coarse biodiesel. These impurities are cleaned up by washing with $350 \mathrm{ml}$ of water for $1000 \mathrm{ml}$ of coarse biodiesel. Cleaned biodiesel is methyl ester of non-edible oil ${ }^{12}$.

\section{Parameters Tested and Experimental Procedure}

Engine testing was done in a laboratory at a constant temperature. Engine was started and warmed-up at low idle, long enough to establish the recommended oil pressure, and was checked for any fuel, oil leaks. After completing warm-up procedure, engine was run on no- load condition and speed was adjusted to $1800 \mathrm{rpm}$ by adjusting fuel injection pump. Engine was run to gain uniform speed, after which it was gradually loaded. Experiments were conducted at different levels of load. For each load condition, engine was run at a minimum of $10 \mathrm{~min}$ and data were collected during the last 4-min of operation. Simultaneously, engine exhaust emissions were also determined.

The series of tests are conducted using each of the above mentioned blends, with the engine working at speed of 1500 and at different torque mentioned above. Because of the differences in oxygen content and calorific values of different fuels tested, the analysis is effected at the same engine brake power and not the air fuel ratio or same injected fuel mass.

In each test exhaust smokiness, volumetric fuel consumption rate, and exhaust gas emissions such as carbon monoxide, nitrogen oxides, and total unburned hydrocarbons are measured. From the first measurement brake thermal efficiency (BTHE.) and brake specific fuel consumption (b.s.f.c.) are computed using the fuel sample density and lower calorific value. Table 3 shows the uncertainty of the computed results of various parameters and the accuracy of the measurements.

The analysis of experimental work was started with a preliminary investigation of the compression ignition engine fueled with neat diesel fuel, to find out the exhaust emission levels and engine operating characteristics which constitute a base line can be used to compare with the corresponding cases when using each of the blends forming with the combination of neat diesel and bio-fuel with appropriate proportions. By keeping the same operating conditions the same procedure was repeated for each fuel blend. For every time when the fuel is changed, the lines through which fuel flows were cleaned and then the engine is allowed to run for about 30 minutes to reach and stabilize its new desired conditions.

\section{Results and Discussion}

Investigation was carried out by running engine with different bio-diesel blends and time for $10 \mathrm{cc}$ fuel consumption was calculated. Among two biodiesel blends, Hazelnut bio-diesel blends are showing lesser viscosity than other oils at various temperatures (Fig. 2), may be due lower density of hazelnut biodiesel than others.

\section{A. Brake Thermal Efficiency (BTHE)}

Fig. 2 shows, the brake thermal efficiency (BTHE.) for the conventional neat diesel fuel, and $20 \%$ blends of the two biodiesels with neat diesel fuel, at different loads. BTHE of diesel is showing maximum when compared with two bio-diesels blends mentioned in the work at all different loads (Fig. 3). Among bio-diesels blends, hazelnut bio-diesel blends are showing better BTHE than corn bio-diesel blends. BTHE trend at $20 \%$ blend of bio-diesel is H20 > C20. For other bio-diesel blends, trend is similar to that for $20 \%$ biofuel blend when compare with hazelnut bio-diesel with corn bio-diesel. As load increases, BTHE is also increases, may be due availability of oxygen which helps in complete combustion of the fuel. 


\section{International Journal of Science and Research (IJSR) \\ ISSN (Online): 2319-7064}

Index Copernicus Value (2013): 6.14 | Impact Factor (2015): 6.391

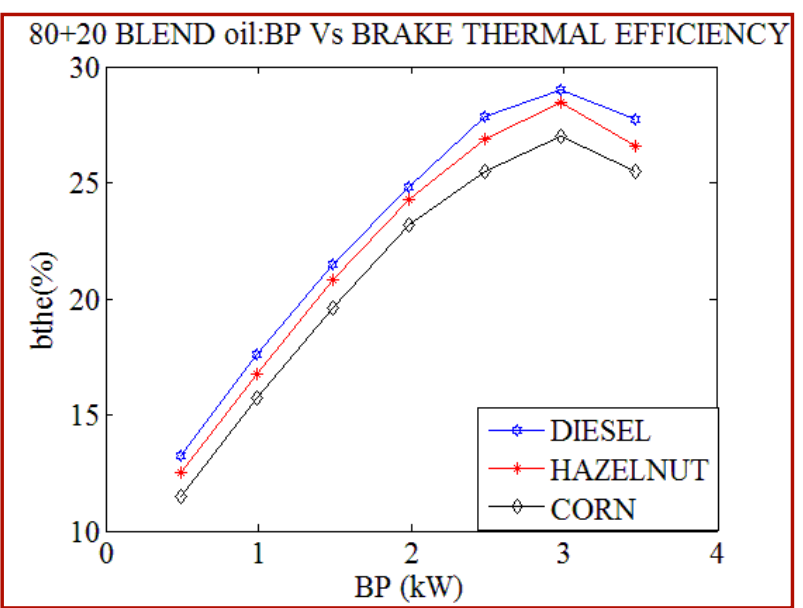

Figure 2: Brake Thermal Efficiency

\section{B. Hydrocarbon (Hc) Emissions}

HC emission of conventional diesel is higher when compared with hazelnut and corn bio-diesel blends at all loads (Fig. 3). Within biodiesel blends comparison, Hazelnut is showing lower $\mathrm{HC}$ emissions than other corn bio-diesel. HC emission trend for $20 \%$ bio-diesel blend is $\mathrm{H} 20<\mathrm{C} 20$ this might be because more oxygen concentration in bio-diesel blends, which promotes better combustion than diesel fuel, Hence, $\mathrm{HC}$ emissions are lower for biodiesel. However for remaining bio-diesel blends for both corn and hazelnut, graph is similar to that of $20 \%$ bio-diesel blend. This also varies along with load as load increases, $\mathrm{HC}$ emissions decrease. However, emissions of hazelnut bio-diesel blends are lower when compared with $20 \%$ blend of corn fuel.

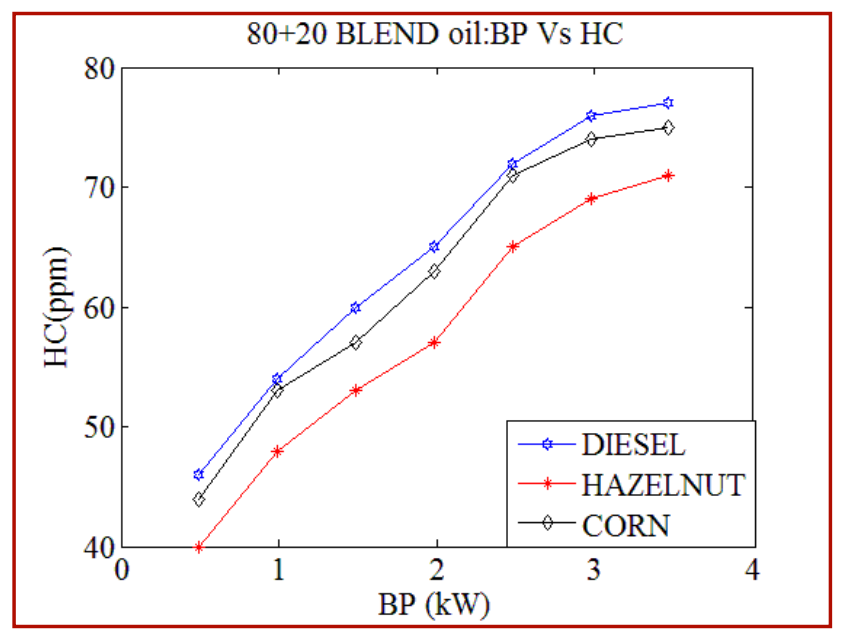

Figure 3: Hydrocarbon Emissions

\section{NOX Emissions}

Fig. 4 shows, the emissions of oxides of nitrogen (NOx) in ppm for the neat conventional diesel fuel, and $20 \%$ blends of the two bio-diesels oils with neat diesel fuel, at different loads. It is observed that the NOx emission from all biodiesel blends mentioned above are higher than corresponding neat diesel fuel. From the discussion made above the lower cetane number of bio-diesel blends (higher ignition delay) may be the reason to increase NOx emissions. For biodiesels Hazelnut and corn, hazelnut is showing minimum NOx emissions than other oils. $\mathrm{NO}_{\mathrm{x}}$ emissions trend at $20 \%$ blend of biodiesel is as $\mathrm{H} 20<\mathrm{C} 20$ may be due to the low cetane number of biodiesel, which lead to ignition lag and causes to accumulate large amount of un burned mixture of air and bio-fuel. This accumulated charge after reaching the self ignition condition will burn at a time causes better combustion than diesel. As a result, the adiabatic flame temperature or maximum temperature inside cylinder is more in case of biodiesels than diesel. Hence, this catalyzes reactions for oxidation of nitrogen and hence NOX emissions are more for biodiesels. For other bio-diesel blends, trend is similar to that for $20 \%$ bio-diesel blend when compare with hazelnut bio-diesel with corn bio-diesel.

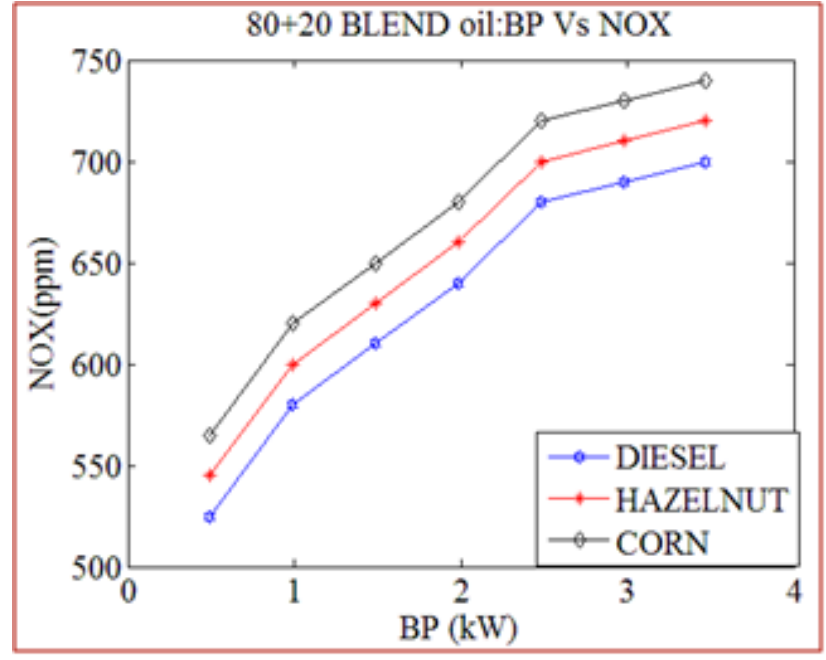

Figure 4: $\mathrm{NO}_{\mathrm{X}}$

\section{Co Emissions}

Fig. 5 shows, the $\mathrm{CO}$ emission of conventional diesel is higher when compared with hazelnut and corn bio-diesel blends at all loads (Fig. 3). Within biodiesel blends comparison, Hazelnut is showing lower $\mathrm{CO}$ emissions than other corn bio-diesel. CO emission trend for $20 \%$ bio-diesel blend is $\mathrm{H} 20<\mathrm{C} 20$ this might be because more oxygen concentration in bio-diesel blends, which promotes better combustion than diesel fuel, Hence, $\mathrm{CO}$ emissions are lower for biodiesel. However for remaining bio-diesel blends for both corn and hazelnut, graph is similar to that of $20 \%$ bio-diesel blend. This also varies along with load as load increases, CO emissions decrease. However, emissions of hazelnut bio-diesel blends are lower when compared with $20 \%$ blend of corn fuel.

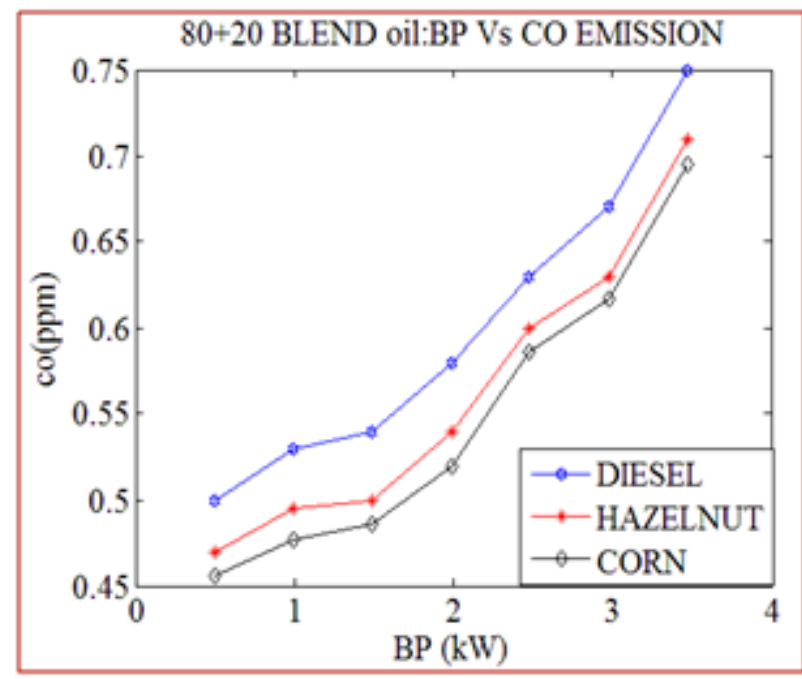

Figure 5: Co Emissions 


\section{International Journal of Science and Research (IJSR) \\ ISSN (Online): 2319-7064}

Index Copernicus Value (2013): 6.14 | Impact Factor (2015): 6.391

\section{E. Smoke Density}

Fig.6 shows the smoke density for the conventional diesel fuel, and $20 \%$ blending of hazelnut and corn bio-diesel with diesel fuel, at varying loads. It is observed that the viscosity of these bio-fuel blends is higher than the ones for the corresponding neat diesel fuel.

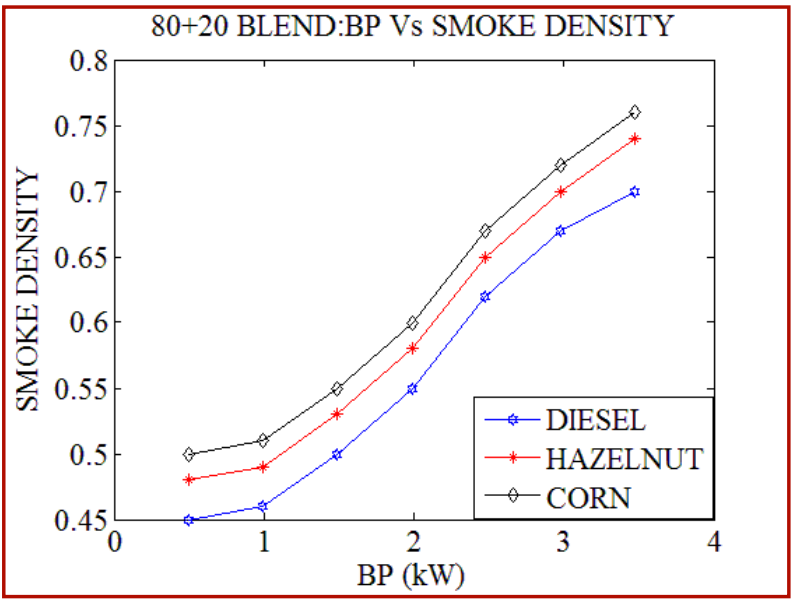

Figure 6: Smoke Density

\section{F. Brake Specific Fuel Consumption}

Fig. 7 Depicts the brake specific fuel consumption (b.s.f.c.) in $\mathrm{kg} / \mathrm{kW} \mathrm{h}$ (kilograms per kilowatt and hour) for the neat conventional diesel fuel, and blends of $20 \%$ of hazelnut and corn bio-diesel saperately with and normal diesel fuel at all loads. The quantity of mass flow rate of bio-diesel blend is analyzed from the respective volume flow rate value which is measured and the density of the fuel blends which is computed by considering the densities of the fuel using and the ratio of fuel blends involved in the experimental work. Since the evaluation of work is made on the constant speed and same load which is translated in to the same engine power, and these values are proportional to the mass flow rate of fuel. It is to be observed that the air mass flow rate remains same under the same operating conditions.

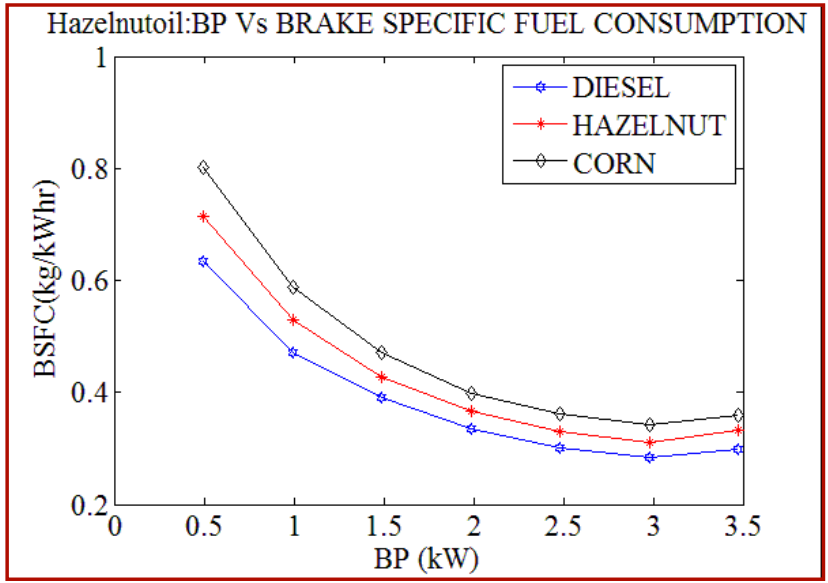

Figure 7: Brake Specific Fuel Consumption

\section{G. Exhaust Gas Temperatures}

Exhaust gas temperature Exhaust gas temperature (EGT) varied with load and the results for bio-diesel blends along with diesel are represented in Figure 8. EGT of all the tested bio-diesel blends used in the present work is increased with BP. EGT of B20 was higher than that of diesel fuel at the all loads due to the blends' higher viscosities, which resulted in poorer atomization, poorer evaporation, and extended combustion during the exhaust stroke. As the amount of biofuel content increases (B20, B25) then viscosity also increases, and, as a result, EGT of the blends was higher than that of diesel fuel due to deterioration in combustion and more fuel being oxidized.

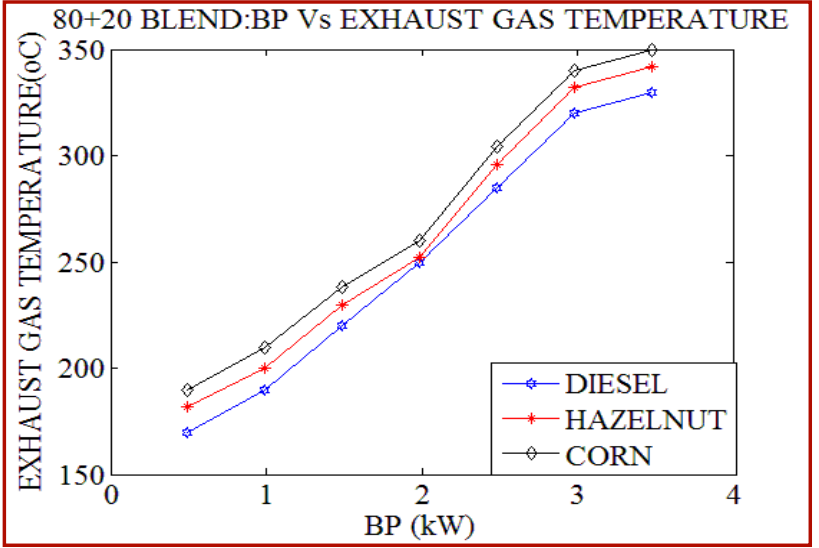

Figure 8: Exhaust Gas Temperatures

\section{Summary and Conclusions}

An experimental work was carried out to evaluate for the comparison of the performance parameters and exhaust emission characteristics of two different bio-diesels viz. hazelnut bio-diesel, corn bio-diesel. with the analysis it is concluded than these bio-diesel blends can be successfully used as alternative to the diesel fuel at blend ratios of 20/80 (by vol.) in traditional CI engine without any modifications.

Number of tests is performed with hazelnut and corn biodiesel blends as fuel in the traditional engine without any modifications where the engine is working at different loads. In each test, exhaust smokiness, exhaust gas, temperatures and exhaust regulated gas emissions such as nitrogen oxides (NOx), carbon monoxide (CO), and total unburned hydrocarbons (HC) are analyzed. Brake thermal efficiency and brake specific fuel consumption are calculated from measured fuel volumetric flow rate and calorific values.

The exhaust smoke emission was reduced by the use of all hazelnut and corn bio-diesell blends along with the respective neat conventional diesel fuel, hazelnut oil blends perform better when compared with remaining all four biofuels.

The NOx emission was marginally increased with the use of these bio-diesel blends with respect to those of the neat conventional diesel fuel.

The CO emissions was decreased considerably with the use of these bio-diesel blends when compare with diesel fuel.

The HC emissions were decreased with the use of all biodiesel blends with respect to those of the neat diesel fuel, with this increase being higher the higher the percentage of bio-fuel in the blend. 


\section{International Journal of Science and Research (IJSR) \\ ISSN (Online): 2319-7064}

Index Copernicus Value (2013): 6.14 | Impact Factor (2015): 6.391

The engine brake thermal efficiency is slightly lower for hazelnut and corn bio-diesel than the brake thermal efficiency of diesel operated in the same engine. The reason for this is lower calorific values and higher viscosity associated with hazelnut bio-diesel blend.

\section{References}

[1] Rakopoulos CD, Giakoumis EG. Diesel engine transient operation - principles of operation and simulation analysis. London: Springer; 2009.

[2] Pulkrabek WW. Engineering fundamentals of internal combustion engines.2nd ed. New Jersey: Pearson Prentice-Hall; 2004.

[3] Levendis YA, Pavlotos I, Abrams RF. Control of diesel soot, hydrocarbon and NOx emissions with a particulate trap and EGR. SAE paper no. 940460; 1994.

[4] Larsen C, Oey F, Levendis YA. An optimization study on the control of NOx and particulate emissions from diesel engines. SAE paper no. 960473; 1996.

[5] Komninos NP, Rakopoulos CD. Numerical investigation into the formation of $\mathrm{CO}$ and oxygenated and noNOxygenated hydrocarbon emissions from isooctaneand ethanol-fueled HCCI engines. Energy Fuels 2010; 24:1655-67.

[6] Miyamoto N, Ogawa H, Nabi MN. Approaches to extremely low emissions and efficient diesel combustion with oxygenated fuels. Int J Engine Res 2000;1:71-85.

[7] Pepiot-Desjardins P, Pitsch H, Malhotra R, Kirby SR, Boehman AL. Structural group analysis for soot reduction tendency of oxygenated fuels. Combust Flame 2008;154:191-205.

[8] Rakopoulos CD, Michos CN, Giakoumis EG. Studying the effects of hydrogen addition on the second-law balance of a biogas-fuelled spark ignition engine by use of a quasi-dimensional multi-zone combustion model. Proc Inst Mech Eng, Part D, J Autom Eng 2008;222:2249-68.

[9] Abu-Jrai A, Rodriguez-Fernandez J, Tsolakis A, Megaritis A, Theinnoi K, Cracknell RF, et al. Performance, combustion and emissions of a diesel engine operated with reformed EGR. Comparison of diesel and GTL fuelling. Fuel 2009;88:1031-41.

[10] Barlow RS, Karpetis AN, Frank JH, Chen J-Y. Scalar profiles and NO formation in laminar opposed-flow partially premixed methane/air flames. Combust Flame 2001;127:2102-18.

[11] Hansen AC, Kyritsis DC, Lee CF. Characteristics of biofuels and renewable fuel standards. In: Vertes AA, Blaschek HP, Yukawa H, Qureshi N, editors. Biomass to biofuels - strategies for global industries. New York: John Wiley; 2009.

[12] Rickeard DJ, Thompson ND. A review of the potential for bio-fuels as transportation fuels. SAE paper no. 932778; 1993.

[13] Hansen AC, Zhang Q, Lyne PWL. Ethanol-diesel fuel blends - a review. Bioresour Technol 2005;96:277-85.

[14] Rakopoulos CD, Antonopoulos KA, Rakopoulos DC, Hountalas DT, Giakoumis EG. Comparative performance and emissions study of a direct injection diesel engine using blends of diesel fuel with vegetable oils or bio-diesels of various origins. Energy Convers Manage 2006;47:3272-87.
[15] Rakopoulos CD, Rakopoulos DC, Giakoumis EG, Dimaratos AM. Investigation of the combustion of neat cottonseed oil or its neat bio-diesel in a HSDI diesel engine by experimental heat release and statistical analyses. Fuel 2010;89:3814-26.

[16] Rakopoulos CD, Antonopoulos KA, Rakopoulos DC. Experimental heat release analysis and emissions of a HSDI diesel engine fueled with ethanol-diesel fuel blends. Energy 2007;32:1791-808.

[17] Rakopoulos DC, Rakopoulos CD, Kakaras EC, Giakoumis EG. Effects of ethanol- diesel fuel blends on the performance and exhaust emissions of heavy duty DI diesel engine. Energy Convers Manage 2008;49:315562.

[18] Rakopoulos DC, Rakopoulos CD, Hountalas DT, Kakaras EC, Giakoumis EG, Papagiannakis RG. Investigation of the performance and emissions of a bus engine operating on butanol/diesel fuel blends. Fuel 2010;89:2781-90.

[19] Agathou MS, Kyritsis DC. An experimental comparison of non-premixed biobutanol flames with the corresponding flames of ethanol and methane. Fuel 2011;90:255-62.

[20] Barlow RS, Ozarovsky HC, Karpetis AN, Lindstedt RP. Piloted jet flames of $\mathrm{CH} 4 / \mathrm{H} 2 /$ air: experiments on localized extinction in the near field at high Reynolds numbers. Combust Flame 2009;156:2117-28.

[21] Rakopoulos CD, Kosmadakis GM, Pariotis EG. Evaluation of a combustion model for the simulation of hydrogen spark-ignition engine using a CFD model. Int J Hydrogen Energy 2010;35:12545-60.

[22] Graboski MS, McCormick RL. Combustion of fat and vegetable oil derived fuels in diesel engines. Prog Energy Combust Sci 1998;24:125-64.

[23] Demirbas A. Biodiesel fuels from vegetable oils via catalytic and non-catalytic supercritical alcohol transesterifications and other methods: a survey. Energy Convers Manage 2003;44:2093-109.

[24] Srivastava A, Prasad R. Triglycerides-based fuels. Renew Sustain Energy Rev 2000;4:111-33.

[25] Papayannakos N, Rakopoulos CD, Kyritsis S, Lappas A, Chatzigakis A, Chlivinos G, et al. Pilot production and testing of bio-diesel produced from Greek feedstocks. In: Frangopoulos C, Rakopoulos C, Tsatsaronis G, editors. Proc of the 19th Int Conf 'ECOS 2006', vol. 3, Crete, Greece, July 12-14, 2006, p. 1489-97.

[26] Canakci M, Erdil A, Arcaklioglu E. Performance and exhaust emissions of a biodiesel engine. Appl Energy 2006;83:594-605.

[27] Rakopoulos CD, Antonopoulos KA, Rakopoulos DC, Kakaras EC, Pariotis EG. Characteristics of the performance and emissions of a HSDI diesel engine running with cottonseed oil or its methyl ester and their blends with diesel fuel. Int J Vehicle Des 2007;45:20021.

[28] Rakopoulos CD, Rakopoulos DC, Hountalas DT, Giakoumis EG, Andritsakis EC. Performance and emissions of bus engine using blends of diesel fuel with biodiesel of sunflower or cottonseed oils derived from Greek feedstock. Fuel 2008;87:147-58.

[29]Benjumea P, Agudelo J, Agudelo A. Effect of altitude and palm oil biodiesel fuelling on the performance and 


\section{International Journal of Science and Research (IJSR) \\ ISSN (Online): 2319-7064}

Index Copernicus Value (2013): 6.14 | Impact Factor (2015): 6.391

combustion characteristics of a HSDI diesel engine. Fuel 2009;88:725-31.

[30] Bueno AV, Velasquez JA, Milanez LF. Heat release and engine performance effects of soybean oil ethyl ester blending into diesel fuel. Energy 2010. doi:10.1016/j.energy.2010.07.030.

[31] Barsic NJ, Humke AL. Performance and emissions characteristics of a naturally aspirated diesel engine with vegetable oil fuels. SAE paper no. 810262; 1981.

[32] Fort EF, Blumberg PN, Staph HE, Staudt JJ. Evaluation of cottonseed oils as diesel fuel. SAE paper no. 820317; 1982.

Volume 5 Issue 6, June 2016 www.ijsr.net 